Adv. Geosci., 44, 67-77, 2017

https://doi.org/10.5194/adgeo-44-67-2017

(C) Author(s) 2017. This work is distributed under

the Creative Commons Attribution 3.0 License.

\title{
Effects of damaging hydrogeological events on people throughout 15 years in a Mediterranean region
}

\author{
Luigi Aceto, A. Aurora Pasqua, and Olga Petrucci \\ CNR-IRPI (Italian National Research Council, Research Institute for Geo-Hydrological Protection), \\ Via Cavour 4-6 Rende, Cosenza, Italy \\ Correspondence to: A. Aurora Pasqua (pasqua@irpi.cnr.it) and Olga Petrucci (o.petrucci@irpi.cnr.it)
}

Received: 6 December 2016 - Revised: 19 June 2017 - Accepted: 20 June 2017 - Published: 20 July 2017

\begin{abstract}
Damaging Hydrogeological Events (DHE) are defined as rainy periods during which landslides and floods can damage people. The paper investigated the effects of DHE on people living in Calabria (southern Italy) in the period 20002014 , using data coming from the systematic survey of regional newspapers. Data about "fatalities", people "injured" and people "involved" (not killed neither hurt) were stored in the database named PEOPLE, made of three sections: (1) event identification, (2) victim-event interaction, (3) effects on people. The outcomes highlighted vulnerability factors related to gender and age: males were killed more frequently $(75 \%)$ than females $(25 \%)$, and fatalities were older (average age 49 years) than injured (40.1 years) and involved people (40.5 years). The average ages of females killed (67.5 years), injured (43.4 years) and involved (44.6 years) were higher than the same values assessed for males, maybe indicating that younger females tended to be more cautious than same-age males, while older females showed an intrinsic greater vulnerability. Involved people were younger than injured people and fatalities, perhaps because younger people show greater promptness to react in dangerous situations. In the study region, floods caused more fatalities $(67.9 \%)$, injured $(55 \%)$ and involved people $(55.3 \%)$ than landslides. Fatalities and injuries mainly occurred outdoor, especially along roads, and the most dangerous dynamic was to be dragged by flood, causing the majority of fatalities $(71.4 \%)$. These outcomes can be used to strengthen the strategies aimed at saving people, and to customise warning campaigns according to the local risk features and people's behaviour. The results can improve the understanding of the potential impacts of geo-hydrological hazards on the population and can increase risk awareness among both administrators and citizens.
\end{abstract}

\section{Introduction}

Damaging Hydrogeological Events (DHE) are episodes of severe weather that cause landslides and floods (Petrucci and Polemio, 2003; Caloiero et al., 2014; Aceto et al., 2016) and can result in both economic damage and human injuries. DHE occur due to a combination of geologicalgeomorphological predisposing factors, hydrological triggering causes and the presence of vulnerable elements. People are one of these elements, for some aspects, the most valuable one. One effective preparedness measure that helps minimize (if not eliminate) loss of lives is to improve people's behaviour, teaching them to avoid risky actions and promoting safe conducts. Actually, one of the priorities for action in the Sendai Framework for Disaster Risk Reduction is exactly the enhancement of disaster preparedness for effective response (De Groeve et al., 2013).

Scientific literature analysed the effects of all the types of natural disasters on people, by classifying them as short- or long-term impacts (Petrucci and Llasat, 2013). Landslides and floods show different dangerous features, but it is a matter of fact that during DHE they can occur simultaneously and their sequential interactions or cascading effects often originate multi-risk situations. In literature, it is possible to find papers focusing separately on the circumstances in which these two kinds of phenomena affect people in the short term, killing or injuring them. Numerous studies concerning victims caused by floods (Coates, 1999; Jonkman, 2005; Jonkman et al., 2009), and focusing on vulnerability features related to age and/or gender (Vinet et al., 2012), also highlight the road as the most dangerous place to suffer flood damage (Ruin et al., 2007; Petrucci and Pasqua, 2012; Diakakis and Deligiannakis, 2013). On the contrary, papers investigating landslide effects on people are less nu- 
merous than those concerning floods effects (Catapano et al., 2001; Salvati et al., 2010; Petley, 2012; Sepúlveda and Petley, 2015). Other papers focus on the long-term effects on people's health, from either a physical or a psychological point of view (Bilgehan and Kilič, 2008; Fonseca et al., 2009), due to the stress experienced during the event and the loss of houses and/or income. The analysis of past events is basic to highlight both dangerous and cautionary behaviours. This is in accordance with the point of view of European Commission, for which the "application areas for loss databases" are: loss accounting, aiming to record disasters impact, disaster forensic, aiming to identify causes and learn from past, and risk modelling, trying to forecast future losses (De Groeve et al., 2013).

This paper analyses the effects of past DHE on people, in order to infer what actually happened, and to extract descriptive semi-quantitative data that can be used to improve people-event interaction. The next section introduces both the study region and the data search performed for this study, and Sect. 3 describes PEOPLE, the database containing the gathered data. Section 4 presents the data, and Sect. 5 presents discussion and conclusions of the work carried out until now.

\section{The study region and the data search}

The study area is Calabria, the southernmost peninsular region of Italy. It extends for $15080 \mathrm{~km}^{2}$, and includes $409 \mathrm{mu}-$ nicipalities, ranging in size between 2.4 and $292.0 \mathrm{~km}^{2}$. Quaternary tectonic uplift, still active, shaped regional morphology, the elevation of which ranges from sea level to $2260 \mathrm{~m}$. The region is made of allocthonous crystalline rocks, Palaeozoic to Jurassic in age, stacked over carbonate units in the middle Miocene, with Neogene flysch filling tectonic depressions (Monaco and Tortorici, 2000). Annual rainfall (averages: $1150 \mathrm{~mm}$ ) depends on elevation, with the mountainous sectors wetter $(>2000 \mathrm{~mm})$ than the coastal areas $(<500 \mathrm{~mm})$. About $70 \%$ of the rain falls from October to March.

According to the National Institute of Statistic (ISTAT, http://www.istat.it/it/), the region has 1970521 inhabitants, $49 \%$ males and $51 \%$ females, living in 409 municipalities, with an average number of 4790 inhabitants.

Due to geological and climatic conditions, the region is frequently affected by DHE. Official loss-data collection concerning either economic damage or effects on Calabrian people are not available.

The staff of CNR-IRPI of Cosenza (Research Institute for Geo-Hydrological Protection) has been collecting data on DHE since 1970. In 2005, a regional catalogue on a municipal basis of landslides and floods occurred in the region between 1191 and 2005 (814 years) was compiled, (ASICal, http://www.camilab.unical.it/oda/ sitooda_4003.htm). This catalogue does not focus on human consequences, even if it reports data concerning these aspects too. Moreover, several data collections concerning either DHE that affected specific regional sectors (Petrucci and Versace, 2005, 2007; Petrucci et al., 2009; Palmieri et al., 2011) or the entire region (Petrucci et al., 1996; Pasqua and Petrucci, 2016) have been published, in addition to reports about more recent events (Petrucci et al., 2010; Caloiero and Petrucci, 2014). All the documents gathered throughout the years were stored in the Historical Archive of CNR-IRPI of Cosenza. So far, original documents concerning 57 (out of 409) Calabrian municipalities (about 22000 pages) have been scanned and currently are available off-line by visiting the Historical Archive of CNR-IRPI of Cosenza.

Calabrian DHE often caused fatalities and injured people. In the past century, the highest number of fatalities concerned DHE occurred in 1951 (101 fatalities) and 1953 (80 fatalities) (Petrucci and Pasqua, 2014). Currently these values have not been exceeded, even if the cumulate number of DHE's victims is continuously increasing, due to frequent recent events that killed a few people each. These "minor" natural disasters are not included in global loss databases. In fact, as an example, to be included in the well-known Emergency Events DATabase (EM-DAT), a disaster must fulfil at least one of the following criteria (http://www.emdat.be/guidelines):

a. Deaths: 10 or more people deaths;

b. Affected: 100 or more people affected/injured/homeless;

c. International appeal: declaration by the country of the "state of emergency" and/or an appeal for international assistance.

As others Mediterranean regions, Calabria is frequently affected by events under these severity thresholds. These events cannot be included in global databases, and this justifies the local data collection about DHE's impact (Llasat et al., 2013), and the creation of the database PEOPLE presented in this paper.

\section{PEOPLE database}

For the present paper, the database named PEOPLE has been built. In order to allow to other researchers to use the long series of data collected, we uploaded PEOPLE database on Mendeley website (Petrucci et al., 2017). This database contains data about all the events that caused human consequences in Calabria in a 15 -year period. During 12 personmonths, 5475 daily editions of two regional newspapers (La Gazzetta del Sud and Il Quotidiano della Calabria), published between 1 January 2000 and 31 December 2014, were analyzed, and information on effects on people was selected.

The sections of PEOPLE database are described in Table 1 . 
Table 1. Structure of PEOPLE database.

\begin{tabular}{llll}
\hline & \multicolumn{3}{c}{ Event identification } \\
\hline Time of the event & Type of phenomenon & $\begin{array}{l}\text { Victim } \\
\text { identification }\end{array}$ & Type of involvement \\
\hline - ID (YYMMDD\#) & Landslides & - Name & - Fatalities \\
- Year & - Landslide & - Surname & - Injured \\
- Month & - Debris flow & - Gender & - Involved people \\
- Day & - Rock fall & - Age & \\
& Floods & & \\
& - Flood (river or torrent) & & \\
& - Urban flooding (urban \\
& drainage systems) & \\
\hline
\end{tabular}

\begin{tabular}{|c|c|c|c|}
\hline \multicolumn{4}{|c|}{ Victim-event interaction } \\
\hline Places of the event & Condition & Activity & Dynamic \\
\hline $\begin{array}{l}\text { Municipality } \\
\text { Place } \\
\text { Indoor } \\
\text { - Public/private building } \\
\text { - Hospital } \\
\text { - Bungalow } \\
\text { - School } \\
\text { - Hotel } \\
\text { Outdoor } \\
\text { - Road } \\
\text { - Railway } \\
\text { - Bridge } \\
\text { - Riverbed/riverside } \\
\text { - Campsite/tent } \\
\text { - Underpass/tunnel } \\
\text { - Beach } \\
\text { - Countryside } \\
\text { - Ford }\end{array}$ & $\begin{array}{l}\text { - Laying } \\
\text { - Standing } \\
\text { - By car } \\
\text { - By van/caravan } \\
\text { - By tractor } \\
\text { - By truck } \\
\text { - By minivan/bus } \\
\text { - By train }\end{array}$ & $\begin{array}{l}\text { - Sleeping } \\
\text { - Working } \\
\text { - Travelling, going to } \\
\text { home/work } \\
\text { - Rescuing someone } \\
\text { - Fishing } \\
\text { - Recreational } \\
\text { activities }\end{array}$ & $\begin{array}{l}\text { - Blocked in flooded room } \\
\text { - Surrounded by water/mud } \\
\text { - Fallen into a river } \\
\text { - Involved in a road collapse } \\
\text { - Involved in a building collapse } \\
\text { - Involved in a derailment } \\
\text { - Fallen down in a slope } \\
\text { - Hit by a landslide } \\
\text { - Buried by a landslide } \\
\text { - Dragged by flood }\end{array}$ \\
\hline \multicolumn{4}{|c|}{ Effects on people } \\
\hline Causes of death & & \multicolumn{2}{|l|}{ Types of injuries } \\
\hline $\begin{array}{l}\text { - Drowning } \\
\text { - Collapse } \\
\text { - Poly-trauma } \\
\text { - Poly-trauma and suffoca } \\
\text { - Suffocation }\end{array}$ & & \multicolumn{2}{|c|}{$\begin{array}{l}\text { - Shock } \\
\text { - Contusions } \\
\text { - Contusions and shock } \\
\text { - Contusions and abrasions } \\
\text { - Abrasions } \\
\text { - Abrasions and shock } \\
\text { - Fracture to arms/legs } \\
\text { - Wound to arms/legs and cranial trauma } \\
\text { - Poly fractures } \\
\text { - Stroke } \\
\text { - Cranial trauma } \\
\text { - Thoracic trauma }\end{array}$} \\
\hline
\end{tabular}

\subsection{The section event identification}

- Time of the event: it contains year, month and day in which the event occurred. The record identification, $I D$, is made of a combination of year (YY), month (MM), day (DD) of the event and a progressive record number (\#\#).

- Type of phenomenon: the phenomena that damaged people are sorted in two main groups: landslides and floods. 
- Victim identification: it reports name, surname, age and gender of the victims. Name and surname, when available, allowed the exact identification of the people affected, avoiding double counts that can occur in cases where only generic descriptions were available (i.e. "a man died"). Generally, newspapers report quite detailed information on people killed and injured, and nonsystematic information about people involved.

- Type of involvement: here, persons are classified as: $f a-$ talities, injured, and involved people. In the recommendations for a European approach to standardize loss databases (De Groeve et al., 2013), damaged people were classified as killed or injured. In our database, we introduced involved people, which are persons involved but neither killed nor injured, as explained above. People involved, despite were exactly in the place where the events could have hurt or killed them, were neither hurt nor killed. Thus, they may be (a) those who displayed hazardous behaviour, (b) those who were able to protect themselves, (c) people who acted as nonprofessional rescuers. The information on involved people is underestimated because, especially for large events, the reporters generally use collective measures (e.g., "tens of people") without reporting the exact number of people. If we translate the colloquial "frequency words" into numbers, a rough assessment of the number of people involved can be obtained. We assumed some/a few people $\approx 4$; several people $\approx 8$; numerous/tens of people $\approx 10$; many people $\approx 15$; more than hundred people $\approx 100$.

\subsection{The section victim-event interaction}

- Places of the event: municipality and place where the event occurred, classified in 5 indoor and 9 outdoor.

- Condition: describes the condition of people in the moment they were affected, listed in 8 main types.

- Activity: describes the activity carried out by victims at the moment of the event, summarised in 6 main types.

- Dynamic: describes the dynamic of people-event interaction, sorted in 10 main types.

\subsection{The section effects on people}

- Causes of death: sorted in 5 possible types;

- Types of injuries: sorted in 12 possible types.

It must be taken into account that all the categorizations of PEOPLE were carried out using the data-sources available for the study region in the analyzed period. Then, this scheme must be considered as an initial outline for data systematization. In other geographical frameworks, different situations can occur, and the list must be updated accordingly. For example, in some countries, people after floods can suffer for snakes beats (Shajaat Ali, 2007), but this circumstance is practically impossible in Calabria.

\section{Data presentation and discussion}

In PEOPLE, the number of fatalities is certain for all the events, while the number of the injured people is certain for the majority of the events. As for involved people, and especially for larger events, the reporters used collective measures, limiting the possibility to determine the exact number of injured people.

Overall, the information gathered is quite detailed for 28 people killed by either floods $(19,67.9 \%)$ or landslides $(9$, $32.1 \%)$, and 280 injured by either floods $(154,55 \%)$ or landslides (126, $45 \%)$. Non-systematic information on 3211 people involved by either floods $(1777,55.3 \%)$ or landslides $(1434,44.7 \%)$ (Table 2) were also collected.

\subsection{Fatalities}

In 5 of the 15 years of the study period $(2001,2002,2005$, 2007 and 2014) no fatalities occurred. The highest number of fatalities occurred in 2000 , due to the so-called Soverato event, after the name of the municipality on middle eastern coast where 13 people ( $46.4 \%$ of the study period) died because of a flood that affected a campsite. Overall, excluding 2000, the maximum number of fatalities per year was 3 , and they occurred in 2006, during the event that affected Vibo Valentia (middle western coast), while, from 2008 to 2013, 1 or 2 fatalities per year occurred (Fig. 1).

Out of 28 fatalities, the majority were related to floods $(67.9 \%)$ (Table 2). Males represented $75.0 \%$ (21 cases) and females $25.0 \%$ ( 7 cases) of the fatalities. All the females died due to floods, while males died due to both floods and landslides, particularly debris flows ( 6 cases). The age was known for 27 cases, and the average age of fatalities was 49.0 years, particularly 43.7 years for males and 67.5 years for females. The place where fatalities occurred, the condition of the victims, their activity during the event and the dynamic of the accident was known for all the cases. The majority of fatalities occurred outdoor $(16,57.1 \%)$. Neglecting the victims occurred in the bungalows during the single accident of Soverato event, fatalities often occurred on the road $(53 \%)$. These data are shown in Table 3, also sorted by type of damaging phenomenon. Similarly, for the condition and activity of fatalities at the moment of the event, excluding the Soverato event (laying and sleeping), the majority of fatalities were traveling (by some kind of vehicle) or going at home/work $(28.6 \%)$, or were working (17.9\%). As far as the dynamic, the most dangerous was to be dragged by flood, causing $71.4 \%$ of fatalities in different events. Clinical causes of death were known for all the fatalities and the most 


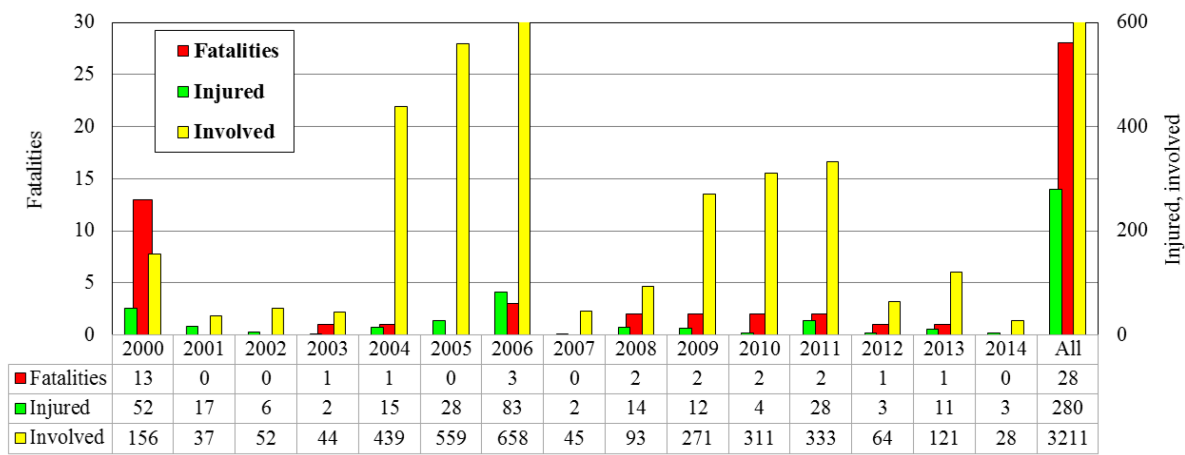

Figure 1. Number of fatalities, injures and involved people in the years of the study period.

frequent were drowning during floods $(78.6 \%)$, and polytrauma and suffocation due to landslides $(10.7 \%)$ (Table 4$)$.

\subsection{Injured people}

As regards the injured, the information is less abundant, due to national legislation protecting privacy and preventing the use of official records (as i.e. fire brigades or hospitals registers). In all the years of the study period, someone was injured by DHE. The highest number of injured people occurred in 2006, during Vibo Valentia event $(83,29.6 \%$ of the total injuries of the study period). High numbers of injured people were also recorded in 2005 (28) and 2004 (15) (Fig. 1).

Out of 280 injuries, the majority were related to floods $(55.0 \%)$ (Table 2). In 142 cases $(50.7 \%)$, the gender was known: $59.2 \%$ were males and $40.8 \%$ females. In 87 cases $(31.1 \%)$, the age was known: the average age of the injured was 40.1 , particularly 37.4 years for males and 43.4 years for females.

The place where people were injured was known for 225 cases $(80.4 \%)$ : the majority of injuries occurred outdoor $(46.8 \%)$ (Table 2). The condition at the moment of the accident was known for 224 cases $(80.0 \%)$, the activity for 213 cases $(76.1 \%)$ and the dynamic for 197 cases (70.4\%); such information is reported in Table 3, also sorted by type of phenomenon. As for fatalities, at the moment of the accident, the majority of the injured were by car or by some kind of vehicle, going to work or home. The majority of those injured were hurt with the dynamic surrounded by water/mud and involved in a derailment, but it must be taken into account that 50 people were injured in 3 cases of derailment, while 58 people were injured in 18 cases as surrounded by water/mud, then this latter dynamic was more frequent than the previous one.

The type of injury was known for 162 cases (57.9\%), mainly caused by landslides $(76.5 \%)$. Among the cases known, shock was the most frequent injury (19.8\%), followed by contusions also associated to shock and abrasions. Landslides were the most common cause of contusions and abrasions, whereas the view of the raising water in the fluvial processes caused cases of shock and stroke (Table 4). For a small number of cases (23), the prognosis, that is the duration of recovery, was known, and it was used as an indicator of the severity of injuries (Table 4).

A small number of data concerning hazardous and selfprotective behaviour was also collected but not presented in table format. Among the injured, 5 cases of hazardous behaviour were identified:

1. a man who was standing fishing at the mouth of a river in flood;

2. two people driving near a river, and rescued by a man who died in the rescue;

3. two people crossing a river by car and rescued by a police officer that injured himself in the rescue.

Among the injured, 54 people showed self-protective behaviour, mainly escaping from a vehicle endangered by a landslide (32 cases).

\subsection{Involved people}

Information on 3211 persons involved in DHE without suffering physical damage was collected: although this information is not systematic, it represents a sort of "lowest damage" level that can be compared to the number of injured people and the fatalities in order to evaluate the dangerousness of each analyzed feature. The gender of the involved people was known only for 330 cases $(10.3 \%)$ : $70.9 \%$ were males and $29.1 \%$ females (Table 2). In 33 cases (1\%), the age of the involved people was known: the average age of the involved people was 40.5 , specifically 39.5 years for males, and 44.6 years for females. Floods involved 1777 people $(55.3 \%)$ and landslides 1434 (44.7\%).

The place where people were involved was known for 3177 cases $(98.9 \%)$, the majority of which occurred indoor $(1828,56.9 \%)$. Conditions at the time of the event were known for 3132 (97.5\%): involved people were mainly standing (1661) or by car (670). Data about the activity was 
Table 2. Fatalities, injured and people involved in DHE in Calabria (period 2000-2014).

\begin{tabular}{|c|c|c|c|c|c|c|c|c|}
\hline \multirow[t]{2}{*}{ Fatalities } & \multicolumn{2}{|c|}{$\begin{array}{c}\text { Total } \\
28\end{array}$} & \multicolumn{2}{|c|}{$\begin{array}{c}\text { Total with } \\
\text { gender known }\end{array}$} & \multicolumn{2}{|c|}{ Males } & \multicolumn{2}{|c|}{ Females } \\
\hline & \# & $\%$ & $\#$ & $\%$ & \# & $\%$ & \# & $\%$ \\
\hline Known gender & & & 28 & 100.0 & 21 & 75.0 & 7 & 25.0 \\
\hline Known age & 27 & 96.4 & 27 & 96.4 & 21 & 77.8 & 6 & 22.2 \\
\hline Average age & & & \multicolumn{2}{|c|}{49.0} & \multicolumn{2}{|c|}{43.7} & \multicolumn{2}{|c|}{67.5} \\
\hline Known place & 28 & 100.0 & 28 & 100.0 & 21 & 75.0 & 7 & 25.0 \\
\hline Known condition & 28 & 100.0 & 28 & 100.0 & 21 & 75.0 & 7 & 25.0 \\
\hline Known activity & 28 & 100.0 & 28 & 100.0 & 21 & 75.0 & 7 & 25.0 \\
\hline Known dynamic & 28 & 100.0 & 28 & 100.0 & 21 & 75.0 & 7 & 25.0 \\
\hline Flood & 19 & 67.9 & 19 & 67.9 & 12 & 63.2 & 7 & 36.8 \\
\hline Flood & 19 & 67.9 & 19 & 67.9 & 12 & 63.2 & 7 & 36.8 \\
\hline \multicolumn{9}{|l|}{ Urban flood } \\
\hline Landslide & 9 & 32.1 & 9 & 32.1 & 9 & 100.0 & & \\
\hline Slide & 3 & 10.7 & 3 & 10.7 & 3 & 33.3 & & \\
\hline Debris flow & 6 & 21.4 & 6 & 21.4 & 6 & 66.7 & & \\
\hline \multicolumn{9}{|l|}{ Rock fall } \\
\hline Injured & \multicolumn{2}{|c|}{$\begin{array}{c}\text { Total } \\
280\end{array}$} & \multicolumn{2}{|c|}{$\begin{array}{c}\text { Total with } \\
\text { gender known }\end{array}$} & \multicolumn{2}{|c|}{ Males } & \multicolumn{2}{|c|}{ Females } \\
\hline Known gender & & & 142 & 50.7 & 84 & 59.2 & 58 & 40.8 \\
\hline Known age & & & 87 & 31.1 & 49 & 56.3 & 38 & 43.7 \\
\hline Average age & & & \multicolumn{2}{|c|}{40.1} & \multicolumn{2}{|c|}{37.4} & \multicolumn{2}{|c|}{43.4} \\
\hline Known place & 225 & 80.4 & 141 & 50.4 & 83 & 58.9 & 58 & 41.1 \\
\hline Known condition & 224 & 80.0 & 140 & 50.0 & 82 & 58.6 & 58 & 41.4 \\
\hline Known activity & 213 & 76.1 & 135 & 48.2 & 78 & 57.8 & 57 & 42.2 \\
\hline Known dynamic & 197 & 70.4 & 113 & 40.4 & 70 & 61.9 & 43 & 38.1 \\
\hline Flood & 154 & 55.0 & 82 & 29.3 & 46 & 56.1 & 36 & 43.9 \\
\hline Flood & 143 & 51.1 & 77 & 27.5 & 43 & 30.1 & 34 & 23.8 \\
\hline Urban flood & 11 & 3.9 & 5 & 1.8 & 3 & 27.3 & 2 & 18.2 \\
\hline Landslide & 126 & 45.0 & & & 38 & 63.3 & 22 & 36.7 \\
\hline Slide & 86 & 30.7 & 27 & 9.6 & 24 & 27.9 & 3 & 3.5 \\
\hline Debris flow & 34 & 12.1 & 29 & 10.4 & 12 & 35.3 & 17 & 50.0 \\
\hline Rock fall & 6 & 2.1 & 4 & 1.4 & 2 & 33.3 & 2 & 33.3 \\
\hline Involved & \multicolumn{2}{|c|}{$\begin{array}{l}\text { Total } \\
3211\end{array}$} & \multicolumn{2}{|c|}{$\begin{array}{c}\text { Total with } \\
\text { gender known }\end{array}$} & \multicolumn{2}{|c|}{ Males } & \multicolumn{2}{|c|}{ Females } \\
\hline Known gender & & & 330 & 10.3 & 234 & 70.9 & 96 & 29.1 \\
\hline Known age & & & 33 & 1.0 & 23 & 69.7 & 9 & 27.3 \\
\hline Average age & & & \multicolumn{2}{|c|}{40.5} & & & & 1.6 \\
\hline Known place & 3177 & 98.9 & 326 & 10.2 & 232 & 71.2 & 94 & 28.8 \\
\hline Known condition & 3132 & 97.5 & 319 & 9.9 & 228 & 71.5 & 91 & 28.5 \\
\hline Known activity & 2076 & 64.7 & 258 & 8.0 & 200 & 77.5 & 58 & 22.5 \\
\hline Known dynamic & 3183 & 99.1 & 311 & 9.7 & 217 & 69.8 & 94 & 30.2 \\
\hline Flood & 1777 & 55.3 & & & & & & \\
\hline Flood & 1200 & 67.5 & 109 & 3.4 & 76 & 6.3 & 33 & 2.8 \\
\hline Urban flood & 577 & 32.5 & 89 & 2.8 & 58 & 10.1 & 31 & 5.4 \\
\hline Landslide & 1434 & 44.7 & & & & & & \\
\hline Slide & 1041 & 72.6 & 91 & 2.8 & 70 & 6.7 & 21 & 2.0 \\
\hline Debris flow & 312 & 21.8 & 35 & 1.1 & 24 & 7.7 & 11 & 3.5 \\
\hline Rock fall & 81 & 5.6 & 6 & 0.2 & 6 & 7.4 & & \\
\hline
\end{tabular}



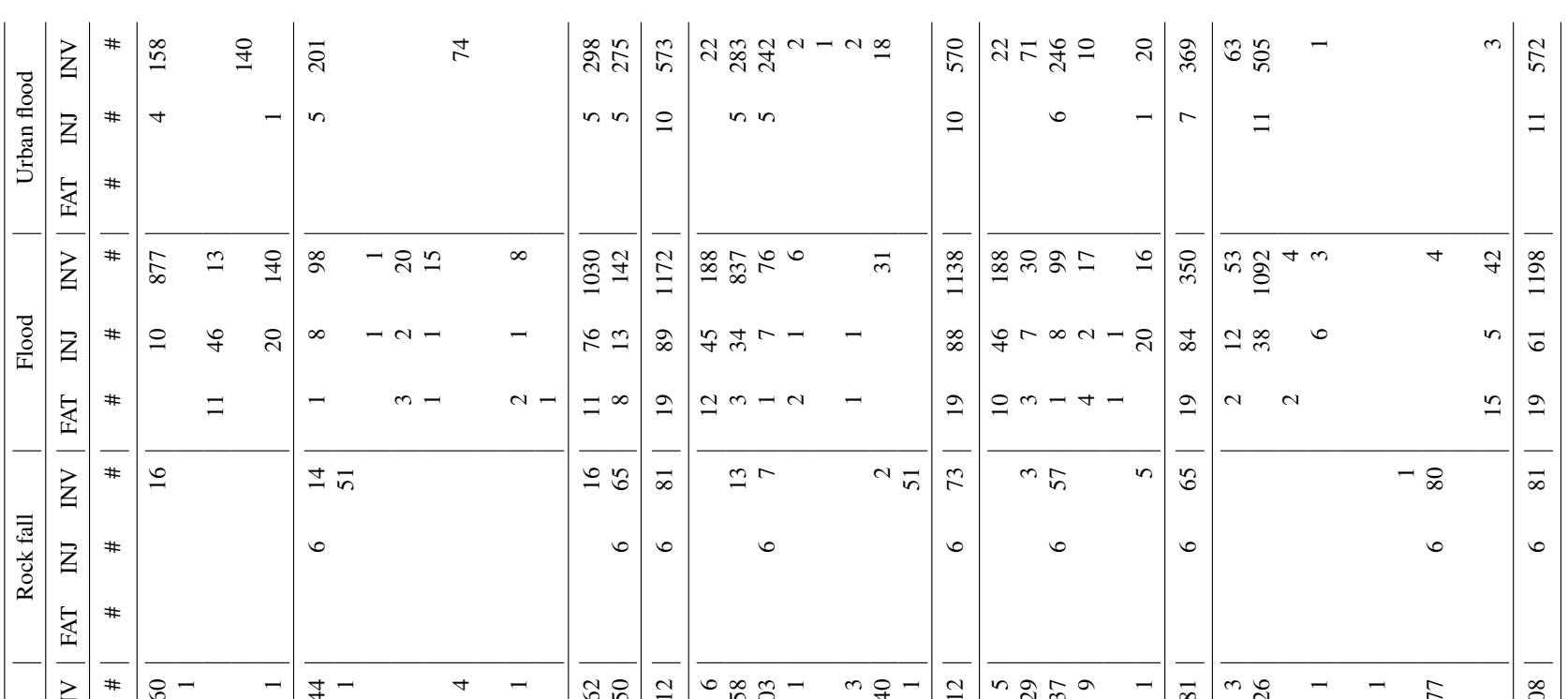

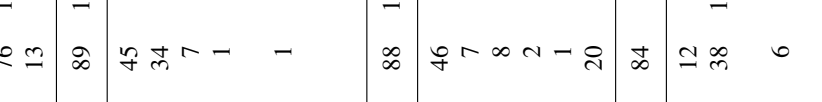

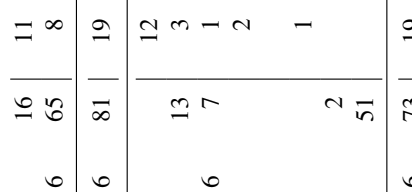

$\frac{0 m-+-}{m n}$

$\frac{a}{6}$

in

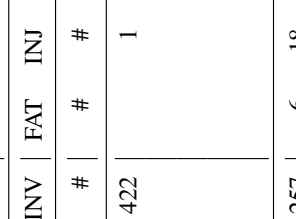

$\stackrel{ \pm}{ \pm}$

至

$\simeq$

宝

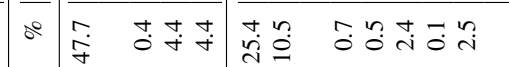

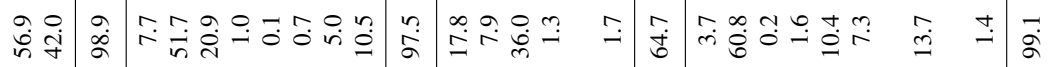

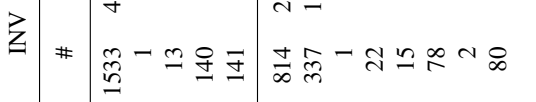

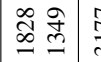

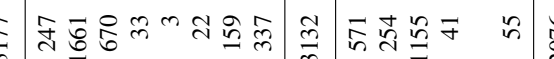

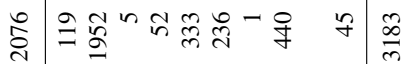

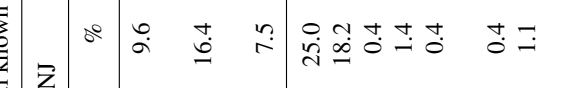

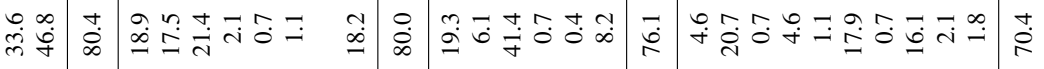

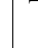


Table 4. Causes of death and types of injures for type of processes.

\begin{tabular}{|c|c|c|c|c|c|c|c|c|c|c|c|c|}
\hline \multirow[b]{3}{*}{ Causes of death } & & & \multicolumn{6}{|c|}{ Landslide: $9(32.1 \%)$} & \multicolumn{4}{|c|}{ Flood: $19(67.9 \%)$} \\
\hline & \multicolumn{2}{|c|}{ Total } & \multicolumn{2}{|c|}{ Slide } & \multicolumn{2}{|c|}{ Debris flow } & \multicolumn{2}{|c|}{ Rock fall } & \multicolumn{2}{|c|}{ Flood } & \multicolumn{2}{|c|}{ Urban flood } \\
\hline & \# & $\%$ & $\#$ & $\%$ & \# & $\%$ & $\#$ & $\%$ & $\#$ & $\%$ & \# & $\%$ \\
\hline Drowning & 22 & 78.6 & 1 & 1.4 & 3 & 20.0 & & & 18 & 78.3 & & \\
\hline Collapse & 1 & 3.57 & & & & & & & 1 & 4.3 & & \\
\hline Poly-trauma & 1 & 3.57 & 1 & 1.4 & & & & & & & & \\
\hline Poly-trauma and suffocation & 3 & 10.7 & & & 3 & 20.0 & & & & & & \\
\hline Suffocation & 1 & 3.57 & 1 & 1.4 & & & & & & & & \\
\hline \multirow[t]{2}{*}{ Total } & 28 & 100 & 3 & 10.7 & 6 & 21.4 & & & 19 & 67.9 & & \\
\hline & \multicolumn{2}{|c|}{ Total } & \multicolumn{6}{|c|}{ Landslide } & \multicolumn{4}{|c|}{ Flood } \\
\hline Type of injuries & \# & $\%$ & \multicolumn{6}{|c|}{ Landslide: 100 (76.5\%) } & \multicolumn{4}{|c|}{ Flood: $38(23.5 \%)$} \\
\hline Shock & 32 & 19.8 & 10 & 11.8 & 2 & 6.1 & & & 12 & 4.4 & 8 & 72.7 \\
\hline Contusions & 26 & 16.0 & 25 & 29.4 & 1 & 3.0 & & & & & & \\
\hline Contusions and shock & 23 & 14.2 & 16 & 18.8 & 2 & 6.1 & & & 5 & 18.5 & & \\
\hline Contusions and abrasions & 26 & 16.0 & 14 & 16.5 & 6 & 18.2 & 2 & 33.3 & 4 & 14.8 & & \\
\hline Abrasions & 8 & 4.9 & 2 & 2.4 & & & 4 & 66.7 & 2 & 7.4 & & \\
\hline Abrasions and shock & 25 & 15.4 & 7 & 8.2 & 16 & 48.5 & & & 1 & 3.7 & 1 & 9.1 \\
\hline Fracture to arms/legs & 1 & 0.6 & 1 & 1.2 & & & & & & & & \\
\hline Wound to arms/legs and cranial trauma & 6 & 3.7 & 3 & 3.5 & 3 & 9.1 & & & & & & \\
\hline Poly fractures & 8 & 4.9 & 3 & 3.5 & 2 & 6.1 & & & 2 & 7.4 & 1 & 9.1 \\
\hline Stroke & 3 & 1.9 & 2 & 2.4 & & & & & 1 & 3.7 & & \\
\hline Cranial trauma & 3 & 1.9 & 2 & 2.4 & & & & & & & 1 & 9.1 \\
\hline Thoracic trauma & 1 & 0.6 & & & 1 & 3.0 & & & & & & \\
\hline \multirow[t]{2}{*}{ Total } & 162 & 57.9 & 85 & 52.5 & 33 & 20.4 & 6 & 3.7 & 27 & 16.7 & 11 & 7 \\
\hline & \multicolumn{2}{|c|}{ Total } & \multicolumn{6}{|c|}{ Landslide } & \multicolumn{4}{|c|}{ Flood } \\
\hline Severity of injuries & \# & $\%$ & \multicolumn{6}{|c|}{ Landslide: 21 (91.3\%) } & \multicolumn{4}{|c|}{ Flood: $2(8.7 \%)$} \\
\hline High: prognosis $>20$ days & 7 & 30.4 & 3 & 42.9 & 4 & 28.6 & & & & & & \\
\hline Medium: prognosis $>2: 20$ days & 13 & 56.5 & 2 & 28.6 & 9 & 64.3 & & & 1 & 4.3 & 1 & 4.3 \\
\hline Low: dismissed within a day & 3 & 13 & 2 & 28.6 & 1 & 7.1 & & & & & & \\
\hline Total & 23 & 8.2 & 7 & 30.4 & 14 & 60.9 & & & 1 & 4.3 & 1 & 4.3 \\
\hline
\end{tabular}

known for 2076 cases $(64.7 \%)$ : in $55.6 \%$ of cases, people were involved during their daily activities. The dynamic of the involvement was known for all the cases, and this was the minimum information available in low detailed cases (i.e. tens of people in cars surrounded by water).

Among the involved people, 27 persons showed the following hazardous behaviour in driving some kind of vehicle (not in tables):

1. try to ford a river in flood (17 cases),

2. run along a river in flood (4 cases),

3. entering in a partially flooded underpass (6 cases).

On the contrary, 728 people showed self-protective behaviour, such as escaping outdoor in case of landslide affecting a building (390) or getting on the roof/upper floors during inundations (123).

\section{Discussion and conclusion}

In Calabria, during the study period, fluvial processes affected more people than slope processes, causing $67.9 \%$ of fatalities, $55 \%$ of injuries and $55.3 \%$ of involved people. On average, each year, 1.9 fatalities, 18.7 injured people and 214.1 people involvement occurred, due to either fluvial or slope processes (averages obtained from the values are reported in Fig. 1). In particular, rock fall and urban flood were the only types of phenomena that did not cause fatalities (Table 2).

Based on the available dataset, some clues related to the analysed features can be highlighted.

- Gender and age: females were less vulnerable than males: the percentage of females killed $(25.0 \%)$, injured $(40.8 \%)$ and involved $(29.1 \%)$ were lower than for males. Despite females represent $51 \%$ of Calabrian 
population, males were more frequently affected, in terms of fatalities $(75.0 \%)$, injuries $(59.2 \%)$ and involvement $(70.9 \%)$. The average age of the injured (40.1 years) and involved people (40.5 years) was lower than fatalities (49.0 years), maybe because younger people showed greater promptness to react in dangerous situations. The average age of females killed (67.5 years), injured (43.4 years) and involved (44.6 years) were higher than the same values assessed for males. This can be interpreted as clue of two combined factors: (a) more cautious behaviour of younger females with respect to same-age males, and (b) an intrinsic greater vulnerability of older females, as detectable by the average age of fatalities among females (Fig. 2).

- Place: people were more frequently killed $(57.1 \%)$ and injured $(46.8 \%)$ outdoor, and more frequently involved indoor $(56.9 \%)$. Actually, in public/private buildings, people were frequently involved $(47.7 \%)$, rarely killed $(3.6 \%)$ or injured $(9.6 \%)$; thus, in the study period, buildings did not represent a very dangerous place. On the contrary, people were involved mostly indoor: probably the circumstances to face indoor were less dangerous, and/or they had the ability to cope with them without suffering physical damage. Roads were the most dangerous places, with several people involved $(25.4 \%)$, injured $(25.0 \%)$ and fatalities $(28.6 \%)$.

- Activity: concerning the activities carried out at the moment of the event, and neglecting the 13 victims of the Soverato event, the most frequent activity among fatalities, injured and involved people was traveling or going home/to work.

- Dynamic: the dynamic, surrounded by water/mud can be considered the less dangerous, because it involved several people $(60.8 \%)$, without causing fatalities. By contrast, the dynamic dragged by flood was fatal, causing the highest number of fatalities $(71.4 \%)$, and a few number of injured $(1.8 \%)$ and involved people $(1.4 \%)$. People were quite infrequently involved in such a kind of dynamic, but it was often lethal. The dynamic surrounded by water was more frequent and less dangerous involving several people and hurting a certain number of them, without causing fatalities. Buried by landslide caused both fatalities and injuries.

- Hazardous/self-protective behavior: despite in Calabria floods are very frequent (Petrucci and Versace, 2005, 2007; Petrucci et al., 2009; Palmieri et al., 2011; Pasqua and Petrucci, 2016), Calabrian people seem to underestimate the dangerousness of these processes. Actually, although data about hazardous behaviors were sporadic, all the detected cases were related to males during floods. Moreover, during floods, self-protective behaviors were rare for both injured and involved people, and mainly consisted in getting on the roof/upper

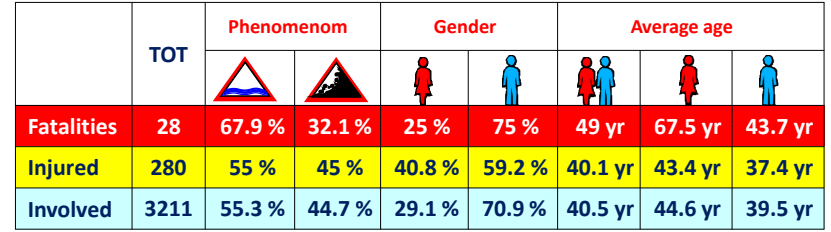

Figure 2. Schematization of phenomenon, gender and age relationships among fatalities, injures and people involved in DHE in Calabria during the study period.

floors. A particular kind of self-protective action was undertaken in Soverato in 2002, two years after the disastrous event that affected the same place 2 years before: a river was flooding a campsite, but the campers promptly built some sort of drainage channels to divert water from the campsite. This can be considered as an assimilation of the lesson from the past; it was due to this experience, that people reacted. Thus, this behavior was the effect of the memory of a "strong event" that affected the "same place" a "few years before". On the contrary, for landslides, no hazardous behavior was reported and self-protective behavior was observed in both injured and involved people. Since the data gathered about the self-protective and dangerous behaviour were not numerous enough, a new research on the 10year period 1991-2000 has been started also to verify if and how people-event interaction has been changing throughout the years.

The gathered information can be used to improve people's awareness throughout educational programs that can be run for schoolchildren or adults, using appropriate language and communication media. Actually, the knowledge of facts and circumstances truly occurred in a region characterised by definite environmental, anthropogenic and cultural features can be proficiently used to customise information campaigns to the specific local framework. Particularly the "people involved" deserve further analyses to highlight right/wrong behavior; these behaviors must be clearly explained to local population, to improve their prompt reaction in coping with damaging hydrogeological events.

Data availability. The database PEOPLE is freely available at: http://dx.doi.org/10.17632/mz2b8f8ys7.1.

Competing interests. The authors declare that they have no conflict of interest.

Special issue statement. This article is part of the special issue "Hydro-related hazardous events and their consequences in the Mediterranean area: knowledge management adaptation". It is a re- 
sult of the 15th Plinius Conference on Mediterranean Risks, Giardini Naxos, Italy, 8-11 June 2016.

Acknowledgements. We are grateful to the Editor and the Referees for the useful suggestions that improved the paper.

Edited by: Giuliano Di Baldassarre

Reviewed by: two anonymous referees

\section{References}

Aceto, L., Caloiero, T., Pasqua, A. A., and Petrucci, O.: Analysis of damaging hydrogeological events in a Mediterranean region (Calabria), J. Hydrol., 541, 510-522, https://doi.org/10.1016/j.jhydrol.2015.12.041, 2016.

Bilgehan, R. and Kiliç, R. K.: The landslides threatening Tasova town (Central Anatolia, Turkey) and their environmental impacts, Environ Geol., 55, 179-190, https://doi.org/10.1007/s00254-007-0974-5, 2008.

Caloiero, T., Pasqua, A. A., and Petrucci, O.: Damaging Hydrogeological Events: a procedure for the assessment of severity levels and an Application to Calabria (Southern Italy), Water, 6, 36523670, https://doi.org/10.3390/w6123652, 2014.

Caloiero, T. and Petrucci, O.: The impact of damaging hydrogeological events on urbanized sectors: the case of 19th November 2013 In Catanzaro (Italy), in: 3rd IAHR Europe Congress, Book of Proceedings, 2014, Porto, Portugal, 8 pp., 2014.

Catapano, F., Malafronte, R., Lepre, F., Cozzolino, P., Arnone, R., Lorenzo, E., Tartaglia, G., Storace, F., Magliano, L., and Maj, M.: Psychological consequences of the 1998 landslide in Sarno, Italy: a community study, Acta Psychiatr. Scand., 104, 438-442, 2001.

Coates, L.: Flood Fatalities in Australia, 1788-1996, Aust. Geogr., 30, 391-408, 1999.

De Groeve, T., Poljansek, K., and Ehrlich, D.: Recording disaster losses, recommendations for a European approach, Scientific and Technical Research series, European Commission Joint Research Centre, Institute for the Protection and the Security of the Citizen EUR, Luxembourg, https://doi.org/10.2788/98653, 2013.

Diakakis, M. and Deligiannakis, G.: Vehicle-related flood fatalities in Greece, Environ. Hazards, 12, 3-4, https://doi.org/10.1080/17477891.2013.832651, 2013.

Fonseca, V. A., Smith, H., Kuhadiya, N., Leger, S. M., Yau, C. L., Reynolds, K., Shi, L., Mcduffie, R. H., Thethi, T., and JohnKalarickal, J.: Impact of a natural disaster on diabetes: exacerbation of disparities and long-term consequences, Diabetes Care, 32, 1632-1638, https://doi.org/10.2337/dc09-0670, 2009.

Jonkman, S. N.: Global perspectives on loss of human life caused by floods, Nat. Hazards, 34, 151-175, 2005.

Jonkman, S. N., Maaskant, B., Boyd, E., and Levitan, M. L.: Loss of life caused by the flooding of New Orleans after hurricane Katrina: analysis of the relationship between flood characteristics and mortality, Risk Anal., 29, 676-698, https://doi.org/10.1111/j.1539-6924.2008.01190.x, 2009.

Llasat, M. C., Llasat-Botija, M., Petrucci, O., Pasqua, A. A., Rosselló, J., Vinet, F., and Boissier, L.: Towards a database on societal impact of Mediterranean floods within the framework of the HYMEX project, Nat. Hazards Earth Syst. Sci., 13, 13371350, https://doi.org/10.5194/nhess-13-1337-2013, 2013.

Monaco, C. and Tortorici, L.: Active faulting in the Calabrian arc and eastern Sicily, J Geodyn., 29, 407-424, 2000.

Palmieri, W., Petrucci, O., and Versace, P.: La difesa del suolo nell'Ottocento nel Mezzogiorno d'Italia, in: IV Quaderno dell'Osservatorio di Documentazione Ambientale, Dip. Difesa del Suolo, UNICAL, Rubbettino, Soveria Mannelli, Italy, 184 pp., 2011.

Pasqua, A. A. and Petrucci, O.: Eventi alluvionali in Calabria nel decennio 1990-1999, available at: https://books.google.it/books? isbn=8895172078, 270 pp., 2016.

Petley, D.: Global patterns of loss of life from landslides, Geology, 40, 927-930, https://doi.org/10.1130/G33217.1, 2012.

Petrucci, O. and Llasat, M. C.: Impact of disasters in Mediterranean regions: an overview in the framework of the HYMEX project, in: Landslide Science and Practice, Vol. 7: Social and Economic Impact and Policies, edited by: Margottini, C., Canuti, P., and Sassa, K., Springer, Berlin, Heidelberg, 137-143, 2013.

Petrucci, O. and Pasqua, A. A.: Damaging events along roads during bad weather periods: a case study in Calabria (Italy), Nat. Hazards Earth Syst. Sci., 12, 365-378, https://doi.org/10.5194/nhess12-365-2012, 2012.

Petrucci, O. and Pasqua, A. A.: Historical climatology of storm events in the Mediterranean: a case study of Damaging Hydrological Events in Calabria, Southern Italy, in: Storminess and Environmental Change, Serie: Advances in Natural and Technological Hazards Research, Vol. 39, edited by: Diodato, N. and Bellocchi, G., Springer Science + Business Media, Dordrecht, 249268, 2014.

Petrucci, O. and Polemio, M.: The use of historical data for the characterisation of multiple damaging hydrogeological events, Nat. Hazards Earth Syst. Sci., 3, 17-30, https://doi.org/10.5194/nhess-3-17-2003, 2003.

Petrucci, O. and Versace, P.: Frane e alluvioni in provincia di Cosenza agli inizi del'900: ricerche storiche nella documentazione del Genio Civile. I Quaderno dell'Osservatorio di Documentazione Ambientale, Dip. Difesa del Suolo, UNICAL, Editoriale Bios, Rende, Italy, 172 pp., 2005.

Petrucci, O. and Versace, P.: Frane e alluvioni in provincia di Cosenza tra il 1930 e il 1950: ricerche storiche nella documentazione del Genio Civile. II Quaderno dell'Osservatorio di Documentazione Ambientale, Dip. Difesa del Suolo, UNICAL, Pubbl. GNDCI N. 2913, Editoriale Bios, Rende, Italy, 247 pp., 2007.

Petrucci, O., Chiodo, G., and Caloiero, D.: Eventi alluvionali in Calabria nel decennio 1971-1980, ISBN-13: 978-88-9050882-0, GNDCI N.1374, Rubbettino Arti Grafiche, Soveria, M. (CZ), 142 pp., available at: http://books.google.it/books?id= JqQtrxZhkpsC, 1996.

Petrucci, O., Versace, P., and Pasqua, A. A.: Frane e alluvioni in provincia di Cosenza fra il 1951 ed il 1960: ricerche storiche nella documentazione del Genio Civile, III Quaderno dell'Osservatorio di Documentazione Ambientale Dip. Difesa del Suolo, UNICAL, Rubbettino, Soveria Mannelli, Italy, 175 pp., 2009.

Petrucci, O., Pasqua, A. A., and Gullà, G.: Landslide damage assessment using the Support Analysis Framework (SAF): the 
2009 landsliding event in Calabria (Italy), Adv. Geosci., 26, 1317, https://doi.org/10.5194/adgeo-26-13-2010, 2010.

Petrucci, O., Aceto, L., and Pasqua, A. A.: "PEOPLE”, Mendeley Data, v1, available at: https://data.mendeley.com/datasets/ mz2b8f8ys7/1, https://doi.org/10.17632/mz2b8f8ys7.1, 2017.

Ruin, I., Gaillard, J. C., and Lutoff, C.: Drivers' risk perception of severe storms hazards in Southern France, in: Fourth European Conference on Severe Storms, 10-14 September 2007, Trieste, Italy, 2007.

Salvati, P., Bianchi, C., Rossi, M., and Guzzetti, F.: Societal landslide and flood risk in Italy, Nat. Hazards Earth Syst. Sci., 10, 465-483, https://doi.org/10.5194/nhess-10-465-2010, 2010.

Sepúlveda, S. A. and Petley, D. N.: Regional trends and controlling factors of fatal landslides in Latin America and the Caribbean, Nat. Hazards Earth Syst. Sci., 15, 1821-1833, https://doi.org/10.5194/nhess-15-1821-2015, 2015.
Shajaat Ali, A. M.: September 2004 flood event in south-western Bangladesh: a study of its nature, causes, and human perception and adjustments to a new hazard, Nat. Hazards, 40, 89-111, 2007.

Vinet, F., Lumbroso, D., Defossez, S., and Boissier, L.: A comparative analysis of the loss of life during two recent floods in France: the sea surge caused by the storm Xynthia and the flash flood in Var, Nat. Hazards, 61, 1179-1201, https://doi.org/10.1007/s11069-011-9975-5, 2012. 